\title{
A panacea for Competition Law Damages Actions in the EU? A comparative view of the implementation of the EU Antitrust Damages Directive in Sixteen Member States
}

\author{
Barry J. Rodger \\ Strathclyde University Law School barry.j.rodger@strath.ac.uk \\ Miguel Sousa Ferro \\ University of Lisbon Law School miguelferro@fd.ulisboa.pt \\ Francisco Marcos \\ IE Law School francisco.marcos@ie.edu
}

\begin{abstract}
This article makes an original contribution to the literature on the developing area of private enforcement of EU competition law. It delivers a significant, rigorous and comprehensive analysis of the transposition across a broad selection of Member States (MS) of a major EU Directive introduced with the aim of harmonising and facilitation competition law damages actions across the European Union. It looks at the implementation of the Directive 2014/104/EU in sixteen MS. It analyses the solutions followed by each of those MS in addressing the various issues raised by the Directive (liability and compensation, joint liability, statute of limitations, quantification of harm, passing-on defence and indirect purchasers claims, access to evidence and collective redress).
\end{abstract}

Keywords: EU Competition Law, Damages, Litigation, Private Enforcement.

\section{Introduction}

Directive 2014/104/EU ('the Antitrust Damages Directive', or 'the Directive') is the latest step in the promotion and facilitation of private enforcement of competition law. ${ }^{1}$ It is binding as to the result to be achieved, but it imposes only a minimum degree of protection and allows MS significant discretion in its transposition. In this article we look at how it has been implemented in sixteen different MS. ${ }^{2}$

This article, which summarizes the results of a broader research project, ${ }^{3}$ analyses the approach adopted in each MS to the transposition of the various peovisions of the Antitrust Damages Directive, focusing especially on potential incomplete or inaccurate transposition, national measures beyond the requirements of the Directive and what motivated them, and inconsistencies between MS which may jeopardize the uniformity of the application of EU Competition Law, absent harmonization by the Court of Justice of the European Union (CJEU). The following

\footnotetext{
${ }^{1}$ Official Journal L349 of December $5^{\text {th }}$ 2014. All articles and recitals mentioned in this paper are those of the Directive unless stated otherwise.

${ }^{2}$ Because of the prevalence of private enforcement practice and significance of the Directive measures for competition litigation in certain States, all of the 'States with Considerable Private Enforcement Experience' within the EU are examined (Belgium, France, Germany, Italy, Spain, The Netherlands and the UK). Four additional countries with developing private enforcement experience are also included (Greece; Ireland; Portugal and Sweden). In addition, we included countries from the May 2004 Accession States (Hungary, Poland and Lithuania). Finally, we selected 2 countries from 'States with Limited Private Enforcement Experience': Cyprus and Luxembourg.

${ }^{3}$ For the purposes of this article, key issues in MS' transposition have not been covered, in particular in relation to the substantive and temporal scope of the transposition measures, and fuller detail of the project and outcomes are set out in The EU Antitrust Damages Directive: Transposition in the Member States (Oxford University Press, eds. BJ. Rodger, MS Ferro \& F Marcos, due for publication in 2018).
} 
sections discusses how the MS have addressed the key issues and controversies arising in the context of the transposition of the Damages Directive.

\section{Who is liable and under which conditions?}

As the Directive purposely chose not to explicitly address the substantive grounds and conditions for liability, it was left to the MS to specify what these may be, within the limits imposed by Arts. 101 and 102 TFEU, together with general principles of EU Law (such as the principle of effectiveness) and in accordance with a systemic and teleological interpretation of the Directive itself..

The most obvious legal controversy, at this level, which the Directive, unfortunately, chose not to address, concerns the liability of the parent company. It is settled that, in the public enforcement of EU antitrust rules, parent companies may be liable for the behaviour of their subsidiaries over which they (solely or jointly) exercise decisive influence, even if they were unaware of the antitrust infringing behaviour, and that this influence may be presumed if they (directly or indirectly) own all or nearly all the share capital of that subsidiary. ${ }^{4}$ However, this question has not been settled in all the MS, regardless of whether NCAs apply only national or also EU competition law (positive examples are Austria, Italy, the United Kingdom and, in part, Hungary). As was recently brought to the forefront by the infamous German "sausage gap", ${ }^{5}$ some NCAs have seen their attempts to comply with this aspect of EU Law blocked by national courts. ${ }^{6}$ This led to the introduction of a harmonising provision in the proposed ECN+ Directive. ${ }^{7}$

More significantly, in the context of the Damages Directive transposition, the same issue of parental company liability will have to be considered in the private enforcement sphere. This has not, as yet, been addressed by the CJEU, and it is likely to raise the same constitutional issues and potential arguments regarding the limits to the primacy of EU Law, as in the public enforcement context. Although the issue was raised during the drafting of the Directive and in several of the MS transposition preparatory works (see, e.g., the Netherlands), almost none chose to address it specifically (the exceptions being Portugal and Spain), instead leaving it up to the courts to decide on the relationship between liability in antitrust and the traditional company law notion of separate legal personality. Interestingly, Germany included measures in its transposition of the Damages Directive to try to resolve its "sausage gap" problem for public enforcement, but did not include any provision in relation to liability in private damages actions.

The use of concepts in the national lex specialis such as "undertaking" (e.g., Belgium, Luxembourg, the Netherlands and Portugal), "agreement" (Cyprus) or "breach of antitrust law" (France), leading, directly or indirectly, back to the

\footnotetext{
${ }^{4}$ See B Cortese "Piercing the Corporate Veil in EU Competition Law: The Parent Subsidiary Relationship and Antitrust Liability" in B Cortese (ed) EU Competition Law. Between Public and Private Enforcement, Kluwer 2014, 73-93; C Koenig "Comparing Parent Company Liability in EU and US Competition Law" 41(1) (2018) World Competition 69.

${ }^{5}$ See e.g.: hhttp://www.bundeskartellamt.de/SharedDocs/Meldung/EN/Pressemitteilungen/2017 /26_06_2017_Bell_Wurstkartell.html.

${ }^{6}$ Se MS Sousa Ferro "The Portuguese «Sausage Gap»: Parent Company Liability for Antitrust Infringements Not Yet Assured in Portugal" 1(3) (2017) European Competition and Regulatory Law Review 266.

${ }^{7}$ See Proposal for a Directive to empower the competition authorities of the Member States to be more effective enforcers and to ensure the proper functioning of the internal market, COM(2017)142 final, Art. 12(3): "Member States shall ensure that the notion of undertaking is applied for the purpose of imposing fines on parent companies and legal and economic successors of undertakings".
} 
competition law concept of economic unit, may all have consequences for the scope of liability of parent companies, subject to interpretation by the national and European Courts. ${ }^{8}$

Considering the traditional approach of many national courts to this issue in public enforcement, the outcome in many MS is fairly predictable. Absent clear instructions from the CJEU, it is suggested that most national courts are likely to refuse to find parent companies liable in line with the CJEU approach to public enforcement liability. The choice of MS legislators to remain silent on this issue is, thus, disappointing, but perhaps inevitable given the hostility of many national private law experts (and judges) to the suggestion that the general rules of parent company liability could be set aside in these situations.

Before the courts of the Netherlands, parental liability in tort for antitrust infringements "is a hotly debated issue", but one District Court has already ruled out parental liability in such contexts, in accordance with what is believed to be the dominant opinion amongst legal scholars. In contrast, the courts of the UK seem to approach the question on the assumption that the CJEU is likely to extend to the private enforcement sphere its case-law on this issue from the public enforcement side, and there is already at least one precedent where parental liability under the single economic unit doctrine was recognized. ${ }^{9} \mathrm{~A}$ similar approach was also taken in a case in Austria. ${ }^{10}$

The Spanish and Portuguese transposition measures stand alone in explicitly dealing with this issue. Both sets of measures establish rules for the civil liability of the parent company for antitrust infringements carried out by subsidiaries. The Spanish law excludes the liability of the parent when it was not able to exercise decisive influence over the subsidiary. The Portuguese law further codifies the CJEU's case-law on the presumption of exercise of decisive influence for shareholdings of at least $90 \%$ in the subsidiary undertaking.

A potentially even more complicated issue concerns the liability of companies within the economic unit, which are not capable of having direct or indirect control over the company which carried out the infringement. Even in the public enforcement context, European case-law has not yet clarified if a subsidiary may be deemed responsible for the behavior of its parent or of a different subsidiary of the group, when it itself did not participate in the infringement. ${ }^{11}$ None of the national transpositions explicitly address this issue (beyond the possible consequences which may derive from the use of concepts such as "undertaking"). The German provision which closed the "sausage gap" for public enforcement refers only to parent companies, ${ }^{12}$ and accordingly does not provide for the imposition of fines on subsidiaries in these situations, nor does it consider the private enforcement

\footnotetext{
${ }^{8}$ In France, the discussion is made more complex by the replacement of a reference to liability of the "undertaking", in a draft version, for a reference to liability of "natural or legal persons".

${ }^{9}$ At least in England and Wales, and notably the Competition Appeal Tribunal ('CAT') in July $14^{\text {th }}$ 2016 Case 1241/5/7/15 (T) Sainsbury's Supermarkets Ltd v. Mastercard Inc \& others [2016] CAT 11.

${ }^{10}$ See Judgment of the Oberste Gerichtshof of August $2^{\text {nd }} 2012$ (case no. 4 Ob 46/12m) 77.4

11 The issue has been addressed, but not decisively so, in: GCEU Judgment of March $11^{\text {th }} 1999$, Siderúrgica Aristrain Madrid (T-156/94) EU:T:1999:53, ๆTा140-142, overturned by CJEU Judgment of October $2^{\text {nd }}$ 2003, Siderúrgica Aristrain (C-196/99P) EU:C:2003:529, TT98-100; and in GCEU Judgment of September 27 th 2006, Jungbunzlauer (T-43/02) EU:T:2006:270, TाT 125-130. See also Opinion AG Kokott in Akzo Nobel (C-97/08P) EU:C:2009:262, 凤97; and Opinion AG Mengozzi in Siemens Österreich (C-231/11P) EU:C:2013:578, ๆ80.

12 See section 81, para 3(a) Gesetz gegen Wettbewerbsbeschränkungen (GWB).
} 
context. In the UK, there are already contradictory rulings in this regard. ${ }^{13}$ A Dutch court has also refused to find a subsidiary liable under the single economic unit doctrine (although, in the specific case, it was able to find it liable under general tort rules). ${ }^{14}$

Finally, in some MS, there has been some consideration given as to whether managers of undertakings may also be held jointly and severally liable for antitrust damages where they were directing or responsible for the actions leading to the infringement. In Germany, a Court of Appeals had interpreted general liability rules as allowing for this and already held managers liable in one case, ${ }^{15}$ and the German transposition measure includes a provision which may be read as confirming this ruling. In Portugal, where managers can also be fined by the NCA for antitrust infringements, some authors suggest that civil liability is also a possibility. ${ }^{16}$

There is a case already pending before the CJEU (referred by a Swedish court) which asks the fundamental question at the base of most liability issues discussed here, specifically whether the determination of who is liable is to be undertaken by applying EU law or national law. The referral asks the CJEU, specifically, about the issue of parent company liability under the single economic unit doctrine and the extent to which it must be applied in parallel with public enforcement case-law on that issue. ${ }^{17}$

\section{Joint liability, immunity recipients and SMEs}

Transposing the rules relating to joint liability, and particularly to the liability of immunity recipients and of SMEs, ${ }^{18}$ has clearly led to discrepancies in approach between MS, including apparent infringements of the duty to faithfully transpose the Directive.

In contrast with many MS (such as Germany, Hungary, Ireland, Italy, Lithuania and the UK), in Belgium, France and Luxembourg these issues have so far been handled, under general rules, not as joint and several liability, but as in solidum

\footnotetext{
${ }^{13}$ See B Rodger "Competition Law private enforcement in the UK courts: case-law developments 2013-2016" [2017] GCLR 10(3) 128-144. See CAT Judgment of July 14 2016 , Sainsbury's $v$ MasterCard et al (1241/5/7/15 (T)), TीT 363(21) to (23); Cooper Tire v Dow Deutschland [2010] EWCA Civ 864; and KME Yorkshire $v$ Toshiba Carrier [2012] EWCA Civ 1190.Cooper Tire $v$ Dow Deutschland [2010] EWCA Civ 864; E KME Yorkshire v Toshiba Carrier [2012] EWCA Civ 1190. Cf Provimi Ltd v Aventis Animal Nutrition SA [2003] ECC 29, ПTा25-31. In the public enforcement context, see $\mathrm{P}$ Hughes "Competition law enforcement and corporate group liability- adjusting the veil" [2014] ECLR 68.

14 Judgment of District Court for the Eastern Netherlands of September $2^{\text {nd }} 2014$, TenneT $v A B B$ (200.126.185, ECLI:NL:GHARL:2014:6766, JOR2014/1265)

${ }^{15}$ See OLG Düsseldorf, 13/11/2013, VI-U (Kart) 11/13, WuW/E DE-R 4117, 4127 et seq.

16 See ME Gomes Ramos "Corporate indemnification: experiences in USA and developments in Germany, Italy and Portugal" 4(2017) European Company and Financial Law Review 723. In the UK, see Safeway Stores Ltd v Twigger (CA), [2010] EWCA Civ 1472; [2011] 2 All E.R. 841; discussed in B Rodger "Competition law litigation in the UK courts: a study of all cases 2009-2012" [2013] GCLR 6(2), 55-67. See also A Robertson "Pulling the Twigger: directors and employees back in the firing line for damages after Jetivia in the Supreme Court?" [2015] 36(8) ECLR 325-326.

${ }^{17}$ Case C-724/17 Vantaan kaupunki.

${ }^{18}$ See C Koenig "Making contribution work: the liability of privileged and non-privileged injurers in EU competition law" (2018) European Competition Journal 14 110; S Peyer "The Antitrust Damages Directive -much ado about nothing?" in M Marquis \& R Cisotta (eds) Litigation and Arbitration in EU Law, E Elgar 2015, 33 at 41-43; E Truli, "Will Its Provisions Serve Its Goals? Directive 2014/104/EU on Certain Rules Governing Actions for Damages for Competition Law Infringements" (2016) Journal of European Competition Law \& Practice 7/5: 299 at 307-308.
} 
liability, which is slightly different and less favourable to victims. While the French and Belgian measures seem to have ensured transposition in accordance with the Directive, the discrepancy was not resolved in Luxembourg, at least regarding socalled "secondary consequences", ${ }^{19}$ which may or may not also be affected by the Directive.

Some MS decided to provide guidance for the distribution of liability between co-infringers and for the exercise of the right of recovery, while others (e.g., Belgium and Hungary) discussed the issue in the drafting of the legislation but did not include a provision on it in the final version of their transposition measure, leaving the courts to rely on general rules.

The French Act (following some prior rulings by national courts) requires liability to be distributed "in proportion to the seriousness of their fault and to their causal contribution to the harm" (and the same criteria have been included in a proposal for a reform of the general civil law rules). In Germany, the measure makes only a broad reference to causality. The Dutch and Swedish measures only make reference to the "share of the harm". In Greece, it is stated that the damage must be equally allocated between co-infringers if the amount of each contribution cannot be determined (a fall back rule which is present also in other MS, as the general rule in civil law). In Hungary, by general rules, any apportionment should be made according to culpability and, subsidiarily, according to contribution and, as a last resort, equally. In Ireland, general rules set fault as the sole criterion, and equal distribution as a last resort. In Spain, the general rule is apportionment according to share of the harm.

The Portuguese transposition is the only measure which actually included a rebuttable presumption: the extent of the liability of each participating undertaking is "presumed to be equivalent to the average of their market shares in the markets affected by the infringement". The same solution was considered in Sweden, following a ruling of the (now) Patent and Market Court that market shares could be used as guidance, but the Government believed an actual presumption would be incompatible with the Directive.

Concerns have been raised (see, e.g., Belgium) about the consequences of joint liability and the possible limitation of the exercise of the right of recovery for undertakings that do not appeal an infringement decision and are ordered to pay compensation for damages caused to clients of other participating undertakings who appeal the decision. Unless any judgment awarding compensation is suspended until the public enforcement infringement decision becomes res judicata in relation to any appealing parties, there is a risk that the decision may be wholly or partly overturned and the undertaking who has already paid compensation in lieu of the other participants will not have the right to be compensated by them.

In the Netherlands, it has been noted that it is uncertain whether infringing undertakings may be held liable for parts of the infringement in which they did not participate. This is especially relevant in the context of single continuous infringements, since an undertaking may be fined by a competition authority for participating in a broad-ranging cartel, of which it was aware, when its actual

\footnotetext{
${ }^{19}$ In these jurisdictions, the consequences of joint liability addressed in the Directive are considered "primary consequences". But there are "secondary consequences", which remain untouched by the Directive and its transposition, and which are different in "solidarity" and "in solidum" situations, such as: whether an action against one infringer interrupts the limitation period against the other jointly liable infringers; whether remission of debt in favour of one infringer liberates all others, and under which conditions; and whether an appeal by one co-debtor benefits the others.
} 
activities are only limited to a small part of it (usually in terms of products or geographic areas). Even if the requirements of the case-law on a single continuous infringement are met in the public enforcement context, it is not yet clear whether the undertaking in question can be held jointly and severally liable, in private enforcement actions, for those parts of the cartel in which it did not participate.

In Belgium, Germany and Lithuania, the restriction on the liability of SMEs has been tempered by making them subsidiarily liable to compensate other injured parties when full compensation could not be obtained from the other participants in the infringement (an extension of the same rule introduced for recipients of immunity). In Germany, the limitation of liability of SMEs to their own direct and indirect purchasers has been restricted to only two of the provisions of national competition law, and not to other provisions which may arguably be considered to also pursue the same objectives as articles 101/102 TFEU, and it has been applied both to claims from injured parties and to co-infringers' claims for contribution (although this is not foreseen in the Directive, it was argued to be necessary for the effectiveness of the intended protection of SMEs).

In what may be argued to be a rectification of an oversight in the Directive, some MS (see,e.g., Germany and Portugal) have extended this limitation of liability for SMEs, o situations in which they acted not only as suppliers, but also for when they acted as purchasers. In the UK, one of the conditions for this protection of SMEs is that they held a market share of less than $5 \%$, not at "any time" during the period of the infringement, as in the Directive, but throughout the period of the infringement. As to the exception which allows the exclusion of joint and several liability when it would irretrievably jeopardize the economic viability of the SME and cause the loss of value of its assets, it has been suggested in France (in a nonbinding document of the legislative procedure) that courts may want to refer, for further guidance, to the Commission Guidelines on the method of setting fines.

In relation to immunity recipients, it has been noted that some MS refer to leniency for participants in "cartels" (e.g., Germany), rather than "secret cartels" as in the Directive, but it is not evident that this will cause any actual discrepancies in practice. The German transposition measure went beyond the Directive both in explicitly stipulating that it is up to the injured parties to prove an inability to obtain compensation from other participants in the infringement, and in clarifying that, within the scope of the relevant exception, immunity recipients are not obliged to compensate claims that have become time-barred against the other infringers.

The Directive also requires MS to ensure that the limitation period for (exceptionally) seeking damages from immunity recipients is reasonable and sufficient, but most MS decided not to adopt a specific solution for this issue. It is not clear whether existing national general rules will be enough to ensure the attainment of this objective, without adequate adaptation in light of, for example, the principle of effectiveness. In Germany, the transposition measure provides that, in these cases, the limitation period will not start before it has been established that it was impossible to obtain full compensation from the other infringers, a provision which is likely to raise doubts and legal controversy.

\section{Access to evidence}

General Issues

Access to evidence was identified as one of the main obstacles to successful litigation in the private enforcement of competition law across the EU. Accordingly, 
the Directive introduced a number of harmonizing provisions in this regard, ${ }^{20}$ even though some rules here are aimed at protecting public enforcement rather than facilitating private enforcement. Nonetheless, in this area there is an extraordinary heterogeneity between the legal orders of the different MS, made worst by an accentuated degree of legal uncertainty when interpreting and applying those national rules. This was so before the transposition of the Directive, and the effects of this heterogeneity are likely to linger in the interpretation of the new rules.

It should be noted from the outset that, while the legislative procedure in several MS brought to the forefront arguments that aspects of the new access rules were justified and appropriate and should be adopted with a broader scope of application than simply for antitrust damages actions, no MS took this step. An initial draft of the Spanish transposition proposed the introduction of new general rules in the Code of Civil Procedure, but this was eliminated from the final version. Thus, all MS have limited the scope of the new access regime to disputes that fall within the specific Damages Directive transposition measures, as defined in the respective MS measures (as noted supra §3.1, the scope of the national regimes varies significantly). In all MS, this is likely to raise concerns about potentially abusive reliance on allegations of antitrust infringements in cases which are more obviously based on infringements of contracts or other legal provisions, in order to benefit from this more favorable access regime. In most of the MS, where the national transposition measure is limited to claims for compensation, it means that parties who seek to prove identical antitrust infringements, but only to obtain a declaration of invalidity or an injunction, will not be able to exercise these rights of access to evidence.

In some MS (Ireland, Luxembourg, the Netherlands, Sweden and the UK), it was believed that the existing national legal framework already largely assured the attainment of the Directive's objectives, and even provided a greater degree of access and protection of claimants' interests. Nonetheless several of the Directive's provisions were still transposed into these legal orders.

However, in the majority of MS, with stricter pre-existing rules and, in some cases, little or no existing culture of discovery of documents, the transposition of the Directive required the introduction of new rules, reproducing all or most of those found in the Directive. In Poland, in particular, it was deemed that the novelty of the new approach, in this legal order, required more detailed regulation at the procedural level.

\section{Changing judicial culture and legal instincts}

The greater challenge in these MS with pre-existing rules will be to overcome the traditional legal instincts of the judiciary, who may tend to interpret the new rules in light of existing general principles of civil procedure. These existing general principles -the interpretation of which is often a matter of debate in each countrywill make it difficult for courts to accept, for example, the idea that parties may need to have access to certain confidential information (and that proportional solutions for such access must and can be found): that it is possible to have access to categories of documents: or that a party must be able to be granted access to information which it is only superficially able to identify and which it cannot a priori

\footnotetext{
${ }^{20}$ For an overview of these provisions see AC Chirita "The Disclosure of Evidence under the 'Antitrust Damages' Directive 2014/104/EU" in V Tomljenović, N Bodiroga-Vukobrat, VM Butorac \& I Kunda (eds) EU Competition and State Aid Rules: Public and Private Enforcement (Springer 2017) 147173.
} 
be sure if it contains relevant information. It may be difficult for some courts to resist the imposition of a burden of justification of the access request which would be impossible to meet and thus deprive the right of access of its effectiveness. ${ }^{21}$

In relation to the first example, many MS (such as Belgium, Cyprus, France, Greece, Italy, Lithuania, Luxembourg, Poland and Portugal) have tackled this concern by providing a list of examples of measures which courts can adopt as compromise solutions to allow solutions in accordance with the principle of proportionality (limits to lawful use of information, redacted versions, nonconfidential summaries, data-rooms, confidentiality circles, etc.). Others, such as the Netherlands, believed that national law already provided judges with the necessary instruments to attain those objectives. It is clearly arguable that absence of specification at EU level of what constitute legitimate grounds for confidentiality, and which situations usually render a document non-worthy of protection (e.g., information older than 5 years) is likely to result in heterogenous enforcement of EU Law across the MS.

In France, a direct and immediate right of appeal to the President of the Paris Court of Appeal, against orders of disclosure of evidence, was instituted. A similar right of appeal was created in Germany and Poland ${ }^{22}$ and may also exist in other legal orders under general rules (see, e.g., Ireland).

Requirements that evidence requested be identified "as precisely and as narrowly" as possible, and supported by available facts and evidence (e.g., Belgium, France, Spain), may reinforce the tendency of courts to be unreasonably demanding when assessing the justification of the request for access.

In this regard, it may be useful to look at how these issues have been tackled in jurisdictions with more experience in providing such access, namely in the context of antitrust damages actions, and which have already been required to strike a balance between protecting the effectiveness of rights of claimants and preventing abusive blanket discovery ("fishing expeditions"). In Ireland, for example, the "necessity" of an item of evidence has been interpreted as something required to avoid an "unfair result of the proceedings" or required to dispose of the case more efficiently (cost saving), within an overall assessment of proportionality. The Irish Supreme Court has tied the assessment of proportionality to a finding of likelihood that a given document or category of documents will contribute to advancing the interests in question, but continues to affirm that, in most cases, a simple determination of relevance is sufficient to grant access. However, it has also decided that a party may not seek discovery of a document in order to find out whether the document may be relevant. It has been suggested that the standards so far applied in Ireland are more stringent than those which are provided by the Directive.

While the Directive only deals, explicitly, with rights of access in the context of a damages action already presented before a court, MS such as Germany, Portugal and Spain decided to introduce pre-trial (rather, pre-litigation) discovery mechanisms (i.e., actions to request access before an application for damages or

\footnotetext{
${ }^{21}$ See, e.g., the varying attitudes of Greek courts in the case-law, concerning the implementation of equivalent provisions transposing the Intellectual Property Rights Enforcement Directive (2004/48/EC, Official Journal L195 of June $2^{\text {nd }}$ of 2004).

22 In Poland, the person ordered to disclose evidence may also request the order to be revised or repealed on the basis of subsequent changes in circumstances.
} 
other remedy is filed; in Ireland ${ }^{23}$ and in England and Wales, these mechanisms are a commonly used tool in litigation, under general civil rules of procedure). In Germany, under pre-existing general rules no such mechanism appeared to be available. An autonomous action for disclosure of evidence is now possible, for the purpose of assessing the right to bring an antitrust damages action, and its initiation leads to the suspension of the limitation period. In Portugal, this autonomous action already existed in general rules, but was little known and never used outside of very specific contexts, and never in antitrust damages proceedings. The transposition Act includes a specific provision in this regard, with the objective of clarifying and promoting awareness about the possibility of using the pre-existing mechanism in this context.

In these legal orders, pre-trial discovery will often be essential for the success of the case, as access to evidence after the application has been filed may allow the applicant to meet the burden of proof, but would come too late to allow it to meet the burden of allegation of facts. The latter must be present in the application and cannot be added at a later stage, with national courts frequently being quite demanding about the degree of specification of the facts which must be alleged. Other MS, such as Lithuania, discussed the possibility of introducing pre-trial discovery (absent from their legal orders), but decided against it, following a minimalist approach to the transposition of the Directive.

Protection of confidentiality and limits to use of evidence

Regarding access to documents included in the files of competition authorities, all analysed MS inevitably transposed the grey and black lists. Although the Directive contradicts the principles affirmed by the CJEU in its case-law on access to leniency applications in ensuring an absolute protection, instead of allowing for the theoretical possibility that, in an exceptional case, circumstances may make it necessary to have access to leniency statements, no MS has challenged this more restrictive approach in its transposition. There is case-law on disclosure in the UK which took on the Pfleiderer and Donau Chemie case-law, which will inevitably need to be reconsidered in light of these new provisions.

A specific problem with the black list is that the Directive seemingly overlooked a problem in its approach to protecting settlement submissions. It places "settlement submissions" in the black list, but then places "settlement submissions that have been withdrawn" in the grey list. The Commission and NCAs became convinced that this was a mistake which would seriously limit the willingness of undertakings to discuss settlements, for fear that claimants would have access to withdrawn submissions after conclusion of the public enforcement case. The Commission has tried to correct this in a subsequent soft-law document, arguably depriving the grey list provision of its effet utile. ${ }^{24}$ Portugal has adopted the same approach in its transposition, on the one hand providing that it is possible to have access to withdrawn submissions, on the other changing the Competition Act to make sure that no undertaking ever has to "withdraw" its submission; it can simply replace it with another and the previous one will be deemed "ineffective". This, like the Commission's identical approach, may be incompatible with the express terms of

\footnotetext{
${ }^{23}$ In Ireland, courts may only order discovery if the applicant has previously requested the holder of the evidence to voluntarily disclose it.

${ }^{24}$ See Commission Notice on the conduct of settlement procedures in view of the adoption of Decisions pursuant to Article 7 and Article 23 of Council Regulation (EC) No 1/2003 in cartel cases (Official Journal C167 of July $2^{\text {nd }}$ 2008), as amended (Communication from the Commission, Official Journal C256 of August $5^{\text {th }} 2015$ ).
} 
the Directive. It leaves no room for the grey list provision to ever be applied, and there is no legal justification to deem that provision invalid. Specifically, it cannot be argued that access to withdrawn settlement submissions would violate the nemo tenetur principle, because such a document would not include a confession of guilt, merely a proposal to confess guilt, which was conditional upon facts which did not subsequently arise.

The Italian transposition has specifically introduced a right for national courts to suspend the damages actions if access to grey listed documents is requested, so as to wait for the end of the proceedings, when those documents become available.

Some MS courts will have to deal with thorny temporal scope issues. In Belgium, France and Luxembourg, for example, access by third parties to confidential information held by the NCA has to date been prohibited by law. In Portugal, it was theoretically possible, but always refused in practice. In Belgium and Portugal, there was an absolute protection of documents submitted together with leniency applications (extending to pre-existing documents). Future requests of access to documents provided to these NCAs, protected under the pre-existing legislation are likely to be contested on the grounds of good faith and legitimate expectations of the parties who submitted them. It is unclear how courts will characterize these rules (procedural/substantive) and what temporal effects will be recognized.

In relation to Greece, it has been suggested that a third party seeking to have access to documents held by the NCA, even to non-confidential information included therein, will continue to have this right only in the context of a complaint it has filed before the NCA, and that this would not be in line with the Directive. In Italy -as will also likely be the case in other MS- the right of access to documents held by the NCA, under Administrative Law, will still be applicable, which may lead to some uncertainty about the interaction of that regime with the transposition of the Directive.

In Sweden, doubts have been raised as to whether unlawfully obtained evidence, in breach of the protection afforded by the black and grey lists, is fully excluded from the courts' assessment, or if it may still be given some (limited) evidentiary value.

An additional problem that may become significant is that the drafting of some of the national transposition provisions appear to refer, exclusively, to documents held by the NCAs, and not to the same documents when held by their authors or third parties. Such rules will have to be carefully interpreted in order to ensure the effectiveness of the relative and absolute protections imposed by the Directive. In some cases, it is uncertain whether these provisions apply only to the national NCA(s), or also to documents in the files of the European Commission or NCAs of other Member States. Another issue that may be of great importance, e.g., for transAtlantic private enforcement (but also, potentially, for the UK's leniency program after Brexit), is that no MS seems to have extended the protection to equivalent documents from competition authorities of third States.

Cyprus has limited the right to use information from the file of the NCA for the purposes of applying national and EU competition law, which may be problematic, for example, in mixed actions, where the documents are relevant to prove facts which are alleged to constitute, simultaneously, infringements of antitrust and of other national rules (civil law, unfair commercial practices, etc.). Indeed, the same issue is likely to arise in other MS. 
As for the right of the NCA to be heard before access is ordered, most MS have created mechanisms by which courts will notify the NCA or European Commission of a request for access to documents included in its files and invite it to submit comments. In Cyprus, the burden of notifying the competition authority is placed on the party requesting access. While the Directive's provision and the respective transposition measures were introduced with requests of access to documents which are obviously and knowingly held by a competition authority in mind, it should be noted that it is certainly possible for a private litigant to request access to documents which have been included in a file (e.g., merger control) of a particular competition authority, without that litigant's, or even both litigants', knowledge.

No MS seemed to consider it necessary to create a special rule concerning the protection of legal privilege (see, e.g., Belgian and Lithuanian reports). However, this may prove to be a problematic issue, considering the discrepancy -well identified in the public enforcement sphere- between the scope of protection of legal privilege under EU Law (excluding in-house lawyers) and the scope of protection under the laws of many MS (including in-house lawyers).

Requesting documents from competition authorities

One potential point of controversy, in a system where documents can only be requested from competition authorities if they cannot be obtained from other persons, is how courts should handle unlawful refusals by parties to submit documents that are also held by the Commission or an NCA. Should they immediately presume the fact in question to be proven, or should they order the competition authority to produce that document? It has been suggested that the implementation of this rule of the Directive will be problematic in practice (see France). In Spain, there are concerns that the duty of secrecy imposed on parties in a public enforcement case may be deemed incompatible with the disclosure of evidence in the framework of private enforcement actions.

To some national legislators, the Directive's solution seemed far too rigid and incompatible with the case by case approach to the assessment of proportionality put forward by the ECJ, e.g., in Pfleiderer and Donau Chemie. In Portugal, earlier drafts provided that national courts could order a competition authority to produce evidence, "namely if no other party or third party can reasonably produce it". This would have fallen short of the prohibition required by the Directive, establishing instead a more flexible and tentative preference for access to be requested from other persons. At the last minute, the drafting was revised, to closely mirror the Directive.

\section{Limitation periods}

The rules on limitation periods, read together with the temporal scope of the Directive and its transposition, provide another of the greatest areas of divergence in approach across the MS.

Generally, all of the 16 studied MS have copied the Directive's provisions into their national law, or, at least, have copied the parts thereof which were not already clearly spelled out in the national general rules on time-barring. All MS have opted to limit the new rules on limitation periods to the scope of this regime, rather than revising their general limitation rules.

Nonetheless, the Directive itself took a rather limited approach to harmonizing time-limits. The express terms of the Directive imply that different limitation periods, running under different rules, will continue to apply in different MS. A minimum level 
of protection is guaranteed, but MS are allowed to provide for longer limitation periods if they decide accordingly.

Thus, for example, the Directive imposes a minimum 5 years limitation period, but allows longer periods to be set. Cyprus, Ireland and the UK (England and Wales) have opted to maintain their pre-existing 6 year time-period, and Luxembourg maintained its 10 (or 30) years deadline.

The Directive allows MS to choose whether the limitation period is suspended (e.g., Belgium, France, Hungary, Poland, Portugal, etc.) or interrupted in light of certain events (see, e.g., Spain and Sweden; and Hungary, for exceptional circumstances such as acknowledgement of the debt), with the latter option leading to longer limitation periods. Nonetheless, there are also discrepancies over the legal consequences of suspension. In Hungary, for example, civil law has typically been interpreted as meaning that, instead of prolonging the deadline for the duration of the suspension, a suspension merely leads to the claimant having a short period ( 3 months or 1 year) to enforce the claim after the suspension has ceased. In the Netherlands, the transposition provides for an "extension", rather than a "suspension", meaning, apparently, that claimants will only have until the infringement decision becomes res judicata, plus one year, to take action. It was widely debated whether this would be inconsistent with the Directive, but the Dutch Government decided that it would be compatible.

The Directive determines that the limitation period cannot begin to run before the conditions stipulated by its provisions are met, but it allows MS to set the starting time at a later moment. This option was taken in Germany, where, in line with the general rules of the Civil Code, the transposition opted for the limitation period to start running only at the end of the year in which the Directive's requirements are met. Additionally, rather than the deadline starting to run from the moment when the claimant could "reasonably be expected to know", German and Greek laws appear to be more protective of claimants, by focusing instead on the moment when they had knowledge or should have knowledge, but for their gross negligence, of the circumstances as set out in the Directive.

Doubts have already been raised (e.g., in Germany and Portugal) about how to interpret the Directive's requirement of knowledge that the behaviour constitutes an antitrust infringement, and whether national law and its interpretation will be compatible therewith. Because the precise determination of the existence of an antitrust infringement is, very often, dependent on access to confidential documents and on complex economic and legal assessments, injured parties may be in a position where they "suspect", and may even "believe", that there was an infringement, but cannot reasonably be said to "know" it. Knowledge, it may be argued, requires a degree of certainty which can only derive from a prior res judicata public enforcement decision, or from a clear cut antitrust infringement, which has already been confessed to or where none of its requirements is reasonably subject to dispute. Very few antitrust infringements will meet this test. For the majority of stand-alone antitrust infringements, this raises the spectre of the limitation period never beginning to run.

This specific discussion has received substantial attention in the UK, where concern has been expressed over whether the knowledge test associated with timebarring should not be placed in parallel with the ability of the claimant to satisfy the "statement of claim" test where one needs to show reasonable grounds for bringing the claim to prevent the action from being thrown out.

The Directive chose not to specifically tackle the absolute time limits set by 
some MS. As long as deadlines only begin to run, in the case of continuous or repeated infringements, at the earliest, on the day the infringement ceased, absolute time limits should not pose a problem when they are considerable (e.g., 20 years in Belgium, France, Greece and Portugal). However, the absolute time limit in Cyprus, Germany and Poland (although subject to slightly different rules) is 10 years, which may bring into question compliance with the principle of effectiveness.

An issue which may prove particularly controversial, and which arguably has led to the most diverse solutions in the MS, concerns the temporal succession of laws (see supra §3.2). The problem begins with the fact that many MS (e.g., Italy, Portugal, the UK) consider time-barring rules to be substantive in nature, whereas the case-law of the CJEU has characterized them as procedural. ${ }^{25}$

In France, a special rule in the transposition measure clarifies that limitation periods that are on-going, but have not yet expired by the entry into force of the new regime, are to be extended in accordance with the new rules, minus the time already elapsed. $A$ contrario, this means that rights which have become time-barred under the pre-existing rules will continue to be deemed time-barred, even if they would not be so under the Directive's rules. The same solution has been expressly provided for in Lithuania. A similar rule is included in the German transposition, but its effects are much more limited, as they seem to relate only to the extension of the deadline from 3 to 5 years, while the beginning and suspension of the deadline continues to be governed by the rules previously in force. In the UK, the new time-barring rules (which are more protective of claimants than pre-existing law) will only apply to infringements which began after the entry into force of the new regime, and do not even apply to continuous infringements which began before and ceased after that moment, provisions which are arguably incompatible with the Directive.

This problem, which will surface in different ways in all MS, is also likely to raise difficult discussions regarding the extent to which the principle of effectiveness of EU Law (and, potentially, also of national law, depending on the legal order) already required the limitation period to be counted according to the rules set out in the Directive (at least when it comes to the starting point and period of suspension during investigations).

Such a wide array of differing solutions manifestly endangers the uniform application of the right to damages arising from infringements of Arts. 101/102 TFEU, and some of these approaches may very well be deemed to be incompatible with the Directive and/or with arts. 101/102 TFEU and the principle of effectiveness. ${ }^{26}$

In France, consumer protection class actions were already subject to the special limitation period of 5 years after the competition authority's final infringement decision, and all follow-on actions already benefitted from a suspensive period during the authority's investigation until the final decision or judicial ruling on appeal.

As noted above (supra §4.1), in some MS, some antitrust disputes have been considered as contractual in nature, rather than falling under tort law, and are likely

\footnotetext{
${ }^{25}$ See CJEU Judgment of November 17 $7^{\text {th }} 1998$, Aprile (C-228/96) ECLI:EU:C:1998:544, $\mid 28$; CJEU Judgment of February $9^{\text {th }}$ 1999, Dilexport (C-343/96) ECLI:EU:C:1999:59, ๆT|41-42; CJEU Judgment of July 11th 2002, Marks \& Spencer (C-62/00) ECLI:EU:C:2002:435, ๆ38; CJEU Judgment of

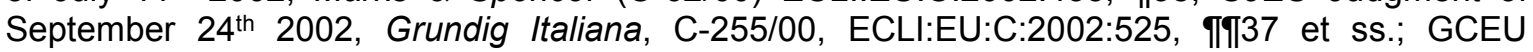
Judgment of April 22 ${ }^{\text {nd }}$ 2016, Ireland v Comission, T-50/06 RENV II, ECLI:EU:T:2016:227, TाT 172173; CJEU Judgment of September $8^{\text {th }} 2015$, Taricco I (C-105/14) ECLI:EU:C:2015:555; CJEU Judgment of December $5^{\text {th }}$ 2017, Taricco /I (C-42/17) ECLI:EU:C:2017:936.

${ }^{26}$ See pending referral in Case C-637/17 Cogeco, mentioned below.
} 
to continue to be characterised in this way in the absence of intervention by the CJEU. For instance, in Hungary, the legislator chose to avoid this problem by specifically providing in the transposition measure that tort rules would be applicable. This may also have consequences at the level of time-barring, whenever different general rules apply for different types of liability (e.g., Belgium). Several MS (see, e.g., Belgium and France) may have transposed the Directive erroneously in relation to the suspension of time-barring as a result of a competition authority investigation, by deeming that investigation as having ended, not, as required by the Directive, at the earliest one year after the infringement decision becomes final or after the proceedings are otherwise terminated, but rather on the day after the decision is adopted/becomes res judicata, or proceedings are otherwise terminated.

Some countries (e.g., France) deemed it necessary to introduce a special time-barring rule to ensure that persons injured by an immunity recipient are not prevented from obtaining full compensation if they wait for litigation brought by coinfringers to be concluded. The deadline for raising an action against immunity recipients will thus only begin to run after they are also able to claim against the coinfringers. Concerns have been raised in France about whether the absence of special rules to prevent time-barring when attempts at consensual dispute resolution fail complies with the Directive's objective in this regard. While there is a pre-existing rule to this effect in the French legal order, it relates only to mediation. Under Spanish Civil Law, when liability is joint and several, a claim started against one co-infringer interrupts the limitation period with respect to the other coinfringers.

Finally, it is worth noting that there is a pending case (referred from a Portuguese court) before the CJEU which seeks clarification on the Directive's timebarring rules, but also, potentially, on the extent to which, in cases involving rights arising from the Treaty, pre-existing national time-barring rules have to be interpreted (or even set aside), to some extent, in line with the solution arrived at in the Directive, as an application of the requirement of the principle of effectiveness of arts. 101/102 TFEU. ${ }^{27}$

\section{Binding force of public enforcement decisions}

The Directive requires MS to make their own authorities' final public enforcement decisions binding in follow-on actions (the 'irrefutable presumption'). It should be kept in mind that decisions of the European Commission were already binding, under Regulation (EC) 1/2003. This binding effect has been reproduced in the transposition procedure in several MS (even though CJEU case-law prohibits the reproduction by national legislators of rules from EU Regulations) ${ }^{28}$. The binding effect of EC decisions has also been acknowledged by the courts of some MS (see, e.g., France). In Cyprus, however, the Competition Act infringes EU Law by treating EC decisions only as prima facie evidence. But, aside from the position in Cyprus, the pre-existing regulation (EC) 1/2003 rule did not appear to cause any significant concerns in the MS.

In contrast, the Directive's rule conferring binding force on national

\footnotetext{
${ }^{27}$ Case C-637/17 Cogeco. The discussion of these time-barring rules in the context of the temporal scope of legal provisions raises questions as to the limits to the primacy of EU Law and became particularly sensitive following the CJEU's surprising response to the Italian Constitutional Court's ultimatum on an issue of time-barring in criminal proceedings in the Taricco case - see CJEU Judgment of December 5 ${ }^{\text {th }}$ 2017, M.A.S. \& M.B. (Taricco II) (C-42/17) ECLI:EU:C:2017:936.

${ }^{28}$ See, e.g., CJEU Judgment of February $2^{\text {nd }}$ 1977, Amsterdam Bulb (50/76) ECLI:EU:C:1977:13.
} 
infringement decisions has met with serious opposition and debate in many MS, where this concept may indeed run counter to established rules and principles of the domestic legal order. It is anticipated that attempts to assert the binding effect of NCA decisions, or of the judgments which confirm them, in MS such as Belgium, France, Italy and Portugal, will be challenged on the grounds that such a binding rule is unconstitutional. It will be argued that it is contrary to the principles of the separation of powers and independence of judges, and that it violates the rights of the defence. In some MS, the principle of independence of judges has been interpreted as meaning that under no circumstance can a judge (even at first instance) be bound by a ruling of another judge (even of the Supreme Court), except in the context of an appeal within a specific dispute, and the same principle applies mutatis mutandis to a decision of an administrative authority. The Directive thus introduces a fundamental shift in what is believed by many to be a core constitutional principle. Setting aside the discussion of the merits of this change, it is foreseeable that the CJEU, the ECtHR and some Supreme/Constitutional Courts will be asked to consider the issue and there may be some disagreement on the outcome, particularly, where the latter may invoke the limits to the primacy of EU law.

The issue is exacerbated in Italy, where the legislator has stipulated that res judicata decisions of the Italian NCA, which have not been appealed (and the deadline for appeal has elapsed), are not fully and immediately binding upon the national courts in private damages actions. In those cases, civil courts must still assess the evidence and facts of the case and are not bound by the NCA's decision if they deem it to suffer from an irreparable fundamental flaw, being illegitimate on procedural or substantive grounds (but having to respect any discretionary margin of the administration in that assessment). This appears to be a manifest infringement of the letter and objective of the Directive, being predicated precisely upon Italian constitutional concerns.

The Directive's rule is not entirely novel for every MS. In Germany, res judicata decisions of the German NCA and of the NCAs of other MS had been given binding effect prior to the Directive. The same was true for decisions by the national NCAs in the UK, ${ }^{29}$ Ireland (where public enforcement decisions are adopted by the courts) and in Lithuania. ${ }^{30}$ In Greece, while the NCA's decisions itself were not binding, review courts' rulings which upheld them were given binding status. France had already created an exception to facilitate consumer class actions, wherein res judicata NCA decisions were binding in follow-on actions.

Several MS transposition processes involved reflection on the value to be awarded to public enforcement decisions from other MS, and even proposed more ambitious solutions in draft Acts, which were ultimately abandoned (e.g., Ireland, Portugal and Spain). The debates certainly identified a degree of mistrust in the legal systems and judicial orders of other EU countries. In some MS, adoption of a binding effect rule was rejected on the basis of the argument that it could not be assured that decisions in other MS would be adopted with the same procedural guarantees and respect for fundamental rights of the defence, a surprising stance in a Union subject to the same fundamental rights, upheld, at the supranational level, by the ECtHR and CJEU. Nevertheless, the matter arguably took up energy

\footnotetext{
${ }^{29}$ Although note here the difficulties in reliance on prior infringement decisions in certain CAT followon cases.

${ }^{30}$ As far as Lithuania is concerned, this is an issue subject to dispute, but this was the interpretation adopted by the Supreme Court in its single ruling on the matter.
} 
and time which was disproportionate to its practical relevance. Since each NCA only adopts decisions relating to effects felt on its territory, the cases where a decision from one MS will be presented to the court of another, subject to EU international private law rules, may turn out to be quite limited. To date there appears to be only one precedent involving this issue, in the Netherlands, relating to a Greek decision. ${ }^{31}$

Ultimately, no MS used its discretion to introduce provision to the effect that infringement decisions by other MS NCAs would have binding force in their own legal order (with the partial exception of Germany, discussed below). For Germany and France (in relation to consumer class actions), their transposition measures actually resulted in a step back from the solution previously adopted. Whereas all MS transposition measures fell short of establishing the binding effect (irrefutable presumption) of such other NCA decisions, divergent approaches have been taken to the legal value that is afforded to such decisions. Most MS rules consider them as constituting prima facie evidence, or 'the beginning' of evidence (see, e.g., Belgium, Cyprus, Greece, Ireland, Italy, Lithuania, the Netherlands, Sweden and the UK; also Germany, for decisions of other MS finding infringements exclusively of foreign competition law). France and Luxembourg simply refer to them as a piece of evidence (preuve). In Poland, a "factual presumption" was established, but the implications thereof are uncertain. The countries which have gone furthest appear to be Hungary, Portugal and Spain, where the decisions create a rebuttable presumption (but, in Spain, only for findings of infringements of EU Competition Law), and Germany, where decisions of other MS are given fully binding effect, but only in so far as they find an infringement of EU competition law or of German competition law. An argument frequently heard in favor of the extension of the legal value was that it would be an advantage in a forum shopping war between the courts of different legal systems.

Another contestable set of issues concerned which decisions are binding and when. There seems to be general agreement that only affirmative decisions are binding, i.e., only the part of an infringement decision that actually finds an infringement, and to the extent to which it does. One consequence is that, while a finding of a restriction by effect will obviously set out the existence of effects on the market in the finding of the infringement itself, it seems arguable that, in infringement decisions on restrictions by object, arguments on purported effects (e.g., to support the amount of fines) will not be binding on courts.

One might anticipate that commitment decisions would have no effect whatsoever, since they do not imply a finding of infringement. A French court has already taken this approach, albeit taking into account the commitment decision when discussing the existence of the infringement (namely, the presence of fault). ${ }^{32}$ A similar approach was adopted by a Hungarian court. ${ }^{33}$ Nonetheless, the CJEU has raised doubts in this context, at least regarding the effects of commitment decisions adopted by the EC, affirming, in a recent judgment, that these are still Commission decisions, and that national courts must "take into account the

\footnotetext{
${ }^{31}$ See Macedonian Thrace Brewery S.A. v. Heineken N.V. and Athenian Brewery S.A., filed on 23 February 2017 before the District Court Amsterdam, C/13/626096, HA ZA 17-321.

32 See Judgment of the Paris Commercial Court of March 30th 2015, DKT v Eco emballages and Valorplast (case no. 2012000109; but overturned on appeal).

${ }^{33}$ See PM Bodnár "Hungary", in A Piszcz (ed), Implementation of the EU Damages Directive in Central and Eastern European Countries, University of Warsaw Faculty of Management Press, 2017, 127 , at 130.
} 
preliminary assessment carried out by the Commission and regard it as an indication, if not prima facie evidence, of the anticompetitive nature of the agreement at issue". 34

The specificities of the Irish system, where NCA findings of infringement are made only by courts, have raised concerns that guilty verdicts will not be sufficiently reasoned and may cause difficulties for follow-on actions. In France, it has been clarified that a decision is considered final and binding on the courts from the moment its finding of infringement becomes res judicata. Thus, in the case of appeals limited to the amount of the fine, the finding of infringement itself is already binding, without having to wait for the result of any appeal that is not concerned with that finding.

A general problem, deriving from the Directive itself, is that decisions become binding when an ordinary appeal is no longer possible. But this does not ensure that an infringement decision will not be subsequently overturned (e.g., by a Constitutional Court ruling, or following an ECtHR judgment) and this may lead to problems regarding its effect.

Finally, legal controversies may be anticipated regarding who is bound by a finding of infringement. The issue debated most often is whether a decision addressed only to a subsidiary will also be binding against the parent company. In England, a court has already confirmed that there is only binding effect for legal persons who are addressees of the decision. ${ }^{35}$ The same position is suggested by the case-law of the French Supreme Court. The parent company's liability may still be established, but will have to be so on general terms, i.e. an unlawful action or omission must be attributed to the parent itself, with a causal link to the damage caused. In countries such as Ireland and Portugal, ${ }^{36}$ the same issue arises in relation to private enforcement actions that are (also) raised against managers or directors.

A reference (from a Portuguese court) is already pending before the CJEU, which may lead to clarifying whether, on the one hand, these provisions of the Directive (and its transposition) are applicable to pending actions, initiated after December 2014, but also whether the principle of effectiveness already required national courts to recognise the binding effect of infringement decisions, even before the entry into force of the Directive. ${ }^{37}$

\section{Compensation, quantification, passing-on and presumptions}

\section{Compensation}

The Directive's emphasis on the right to full compensation, and its prohibition of over-compensation, including by means of punitive and similar types of multiple or exemplary damages, ${ }^{38}$ was not a novelty for the large majority of MS, and, accordingly, required no specific transposition (although, in some cases, the

\footnotetext{
${ }^{34}$ CJEU Judgment of November 23 $3^{\text {rd }}$ 2017, Gasorba (C-547/16) ECLI:EU:C:2017:891. See Spanish Supreme Court (Administrative chamber, sect. 3) Judgment of February $7^{\text {th }} 2018$ (Gasorba $v$. Repsol) ECLI:ES:TS:2018:297.

${ }^{35}$ Emerson Electric Co v Morgan Crucible Co plc [2011] CAT 4, upheld in [2012] EWCA Civ 1559.

36 In Portugal, for example, NCA decisions often apply fines, simultaneously, on undertakings and on their managers/directors.

37 Case C-637/17 Cogeco.

${ }^{38}$ Although the issue has been raised, e.g., in Greece, moral damages should, in principle, not be deemed punitive damages. To the extent that their amount is still assessed on the basis of real damage caused, they are still aimed at placing the injured person, insofar as possible, in the situation he/she would have been in the absence of the infringement.
} 
principle was reaffirmed in the transposition - see, e.g., Cyprus and Spain). In Hungary, it was necessary to create an exception to the general rule in that legal system allowing courts to reduce the amount of compensation awarded on the grounds of equity. In Ireland and in the UK, it required the introduction of a rule prohibiting the award of exemplary damages, which had previously been both theoretically possible and actually awarded by the English courts ${ }^{39}$. The practical impact of the change was limited, in Ireland, by the rarity of damages awarded in antitrust private enforcement actions. Moreover, in the UK, the award of exemplary damages had already been prescribed in 2015 in relation to collective consumer proceedings under the Consumer Rights Act 2015.

While it seems settled that the right to full compensation includes actual losses (damnum emergens), lost profit (lucrum cessans) and interest, the calculation of the latter has proven in particular to be very unclear, as was shown in a recent panEuropean study..$^{40}$ Not only is there great legal uncertainty within many MS, but, the closer one analyses the methods of calculating interest, the greater the degree of heterogeneity of regulation one finds across the EU MS (what type of interest, how to quantify it, when does it begin to accrue, cumulative or alternative compensation for monetary depreciation, etc.). A right to full compensation arising directly from EU Law is incompatible with drastic variations in the amount of compensation one is entitled to, depending on which MS courts handle the claim or, more rigorously, depending on the national law applicable to each specific individual claim (within the same proceedings, identical claimants may be entitled to different interest, depending on the relevant applicable law). Some form of harmonizing intervention by the CJEU or the EU legislator would ameliorate the position here. The Directive's lack of harmonisation of this issue was disappointing, especially considering that the preliminary works that led to its adoption had already identified the lack of consistency of national law in this regard. ${ }^{41}$

Damages, quantification and presumptions

Innovative (in most MS) and very important for the success of damages actions was the introduction of the rebuttable presumption that cartels cause damages. This presumption is present in the transposition laws of all the MS. Nonetheless, in some MS there are doubts as to whether its scope will be broader than the Directive's. In Belgium, for example, the definition of "cartel" may include agreements and concerted practices between non-competing undertakings (see also the definition of "cartel" in Sweden).

Generally, MS have not extended the presumption to infringements based on decisions of associations of undertakings, even though there is often no difference between a cartel decided at meetings between competitors or at a meeting of an association of competitors. This is a weakness in the Directive itself which requires reconsideration and in the meantime it may raise arguments as to the infringement of the principle of equal treatment in some legal orders.

In France, case-law had already introduced not just a presumption of harm (even if merely moral), but a non-rebuttable presumption, and not only for cartels,

\footnotetext{
392 Travel Group PIc (In Liquidation) v Cardiff City Transport Services Ltd [2012] CAT 19

40 See G Monti (Ed) "EU law and interest on damages for infringements of competition law: a comparative report" EUI Law WP 2016/11 (available at: http://cadmus.eui.eu/handle/1814/40464).

${ }^{41}$ See D Waelbroeck, D Slater \& GEven-Shoshan, Study on the conditions of claims for damages in case of infringement of EC competition rules. Comparative Report, August $21^{\text {st }} 2004$ (Ashurst Report) Tा182 and 84-85; Staff Working Paper Annex to Green Paper Damages actions for breach of EC antitrust rules, COM (2005) 672 final, December 19 ${ }^{\text {th }} 2005$, शा 40-41.
} 
but also for infringements based on abuse of dominance. ${ }^{42}$ While a rebuttable presumption will now have to be applied for cartels, it is unclear whether the new regime will require a change in approach in relation to infringements other than cartels. This is another area where the presumption might need to be amended in a future revision of the Directive. Practice shows that there are frequent stand-alone and follow-on abuse cases in the MS, and a rebuttable presumption of harm for these cases would contribute to removing a serious obstacle to successful damages actions.

In Germany, case-law already provided for a lowering of the burden of proof that cartels raise prices, but there was no presumption per se, and the prima facie assumption could be countered by defendants with relative ease (by showing atypical characteristics of the cartel in the question).

One MS that has already moved forward in this regard is Poland, where it was decided to extend the presumption of harm to all antitrust infringements (including vertical restraints and abuse of dominance infringements). Making Poland a more attractive jurisdiction was one of the considerations weighing in favour of this innovation. It has been argued that this may raise difficulties in application in relation to infringements that produced effects. However, it may be noted that if a claimant has already managed to demonstrate that the practice had an anti-competitive effect (and is thus unlawful), an assumption that the anti-competitive effects caused damage does not seem entirely unreasonable.

Generally, there seems to be agreement that the presumption will only apply to the existence of the infringement. Thus, the presumption does not dispense with the need to prove causality (an issue specifically addressed in some MS, such as Greece, Italy and Portugal) and the quantum of harm.

While the claimant's burden of proof of these two elements remains, it must also be recognized that establishing causality should be relatively straightforward in cases of direct contractual relationships, and is made easier for indirect clients by the rule on the proof of passing-on..$^{43}$ As for proof of quantum, there is a necessary deviation from the general burden of proof. As the German Federal Court of Justice (Bundesgerichtshof) has already indicated, a presumption of harm logically implies a conclusion that there are damages (more than zero). ${ }^{44}$ This is also a necessary consequence of the principle of effectiveness. In other words, the claimant will be entitled to "some" compensation, and his/her burden of proof only relates to "how much".

Rare among the laws of the MS is the Hungarian option, dating back to 2009, of imposing a rebuttable presumption that hard-core cartels (directly fixing prices, sharing markets or limiting output) cause a $10 \%$ price increase. The transposition measure kept this rule, with slight adjustments (it now also encompasses buyers'

\footnotetext{
42 See Judgment of the Paris Commercial Court of March 30th 2015, DKT v Eco emballages and Valorplast (case no. 2012000109); Judgment of the Paris Commercial Court of March $30^{\text {th }} 2011$, Numéricable et a. $v$ France Telecom (case no. 2009073089); and Judgments of the Paris Commercial Court and of the Paris Appeal Court of June $26^{\text {th }} 2013$, JCB Sales et a. v SA Central Parts.

${ }^{43}$ However, depending on interpretation of national rules on causality and the attitude of the courts, causality may prove to be a difficult hurdle, especially in abuse cases, as was seen, e.g., in the Lithuanian case LUAB "Klevo lapas" v. AB "ORLEN Lietuva" (Case No 3K-3-207/2010, May $17^{\text {th }}$ 2010).

${ }^{44}$ BGH, 12/7/2016, KZR 25/14, NZKart 2016, 436, 441 -Lottoblock II; see as well Kersting, LMK 2016, 382038, sub 2c).
} 
cartels). However this rule has a limited impact, since it does not cover other anticompetitive practices and it is useful only for surcharge damages, with the burden of proof for other types of damages (e.g., loss of profit) remaining unchanged. The $10 \%$ presumption has also now been introduced in Latvia. ${ }^{45}$

The Directive requires national courts to be empowered to estimate the quantum of damages, if precise quantification is impossible or excessively difficult. Several MS, such as Greece, Lithuania, Portugal and Spain, copied the Directive's rule. But many other MS, such as Belgium, Cyprus, France, Germany, Hungary, Luxembourg and Sweden, decided that transposition was unnecessary, as the Directive's objective was already ensured by general rules. It has been noted, however, e.g. in Cyprus, France and Luxembourg, that it is arguable whether national law truly ensures the Directive's objective will be met, since this will largely depend on the interpretation adopted by the courts.

Swedish law is particularly interesting in this context. It allows courts to estimate damages, not only if it is impossible or excessively difficult to quantify the damages, but also if collating evidence can be presumed to cause costs or inconvenience that is disproportionate to the size of the damage and if the claim for damages concerns a small sum. This is a crucial point, because for many competition damages actions, especially those meant to compensate consumers and SMEs, it is not so much that it is difficult to quantity the damages per se, but rather that doing so would be costly and act as a disincentive on the exercise of the right to damages, making it either too risky or outright irrational. This pre-existing position in Swedish law seems like a meritorious interpretation of the consequences of the principle of effectiveness for the quantification of harm arising from infringements of arts. 101/102 TFEU. Courts of all MS would be encouraged to adopt a similar approach.

Finally, most transposition procedures included debates on the difficulty of arriving at a method of quantifying damages and the need for guidance to be provided to the courts. The Explanatory Memoranda and other documents developed during the legislative procedure in several MS - e.g., Belgium, Greece and Luxembourg - suggest that courts should use the Commission's Practical Guide on the quantification of damages ${ }^{46}$. Portugal has included a reference to the Guide in the transposition measure itself, but merely as a recommendation. Lithuania went further, and its rules actually require courts, and economists submitting economic evidence to courts, to follow the Commission's guidelines.

Indirect damages and passing-on

The European approach to indirect damages was already divergent from the US approach, where only direct customers or suppliers can usually file for damages. This philosophical trans-Atlantic gap, which would, theoretically, ensure a greater level of protection of end consumers (were it not for the procedural obstacles which still prevent their compensation in the EU), has now been widened by the new rules of the Directive which have eased the burdens on indirect claimants.

While the Directive clearly intended that MS would introduce procedural rules to prevent over or under-compensation, particularly in the case of actions for damages issued by claimants from different levels of the supply chain, no MS

\footnotetext{
${ }^{45}$ See J Jerneva \& I Druviete "Latvia" in A Piszcz, A. (ed) Implementation of the EU Damages Directive in Central and Eastern European Countries, 157.

${ }^{46}$ Communication from the Commission on quantifying harm in actions for damages based on breaches of article 101 or 102 of the TFEU (Official Journal C167 of June $13^{\text {th }} 2013$ )
} 
introduced new specific rules. Nonetheless, some MS created new mechanisms to centralize information about on-going and past private enforcement actions (see, e.g., Portugal). While it was argued, during several MS legislative processes, that existing rules already allowed national courts to take measures necessary to ensure that objective (especiallu suspension of proceedings and summoning of third parties to intervene), there are good reasons to be sceptical about the objective actually being met in practice (see, e.g., Netherlands). It is not so much a problem of awareness of other related cases - and whether a court can raise the existence of other actions ex officio (see, e.g., Belgium)-, but rather what the court should and will do after it becomes aware of such other cases.

Short of introducing some kind of EU-wide mechanism for centralization of claims, there does not appear to be any general solution that would prevent abuse and potentially unfair outcomes. It must be recognized that existing legal provision is inadequate to ensure over and under-compensation as a result of parallel actions before different courts, and it also fails to tackle the risk of excessively lengthy procedures in some jurisdictions. In MS where generalist judges may appear to have shown, on occasion, a tendency to adopt delaying tactics and to embrace procedural routes to avoid having to decide a competition law dispute, the possibility of suspension of an action to await the result of another action may prove to be a dangerous tool. It should also be noted that even MS that have centralized jurisdiction in a single court may not avoid this problem completely, as cases may still be allocated to different judges or panels of that court.

The Directive establishes a presumption of passing-on, following proof by the indirect claimant of three requirements. MS have transposed this new rule into their legal orders, but questions have been raised (see, e.g., Germany) as to whether the Directive requires a presumption, not only of passing-on, but of a certain amount of passing-on. It is arguable that the presumption would apply to the full amount of the overcharge. However, others (e.g. the Netherlands) prefer to adopt an approach analogous to that in relation to the presumption of cartel damages and argue that indirect claimants still have the burden of proving how much of the overcharge was passed-on.

It has been considered (see, e.g., Luxembourg) that in claims by direct clients, the fact that the presumption of passing-on only works to the benefit of indirect customers, and not of the infringer, in claims by its direct clients, may be deemed a violation of the principle of equal treatment. In Spain it is argued that the presumption of passing-on is only applicable to first acquirers, and not to purchasers further downstream. In Germany, the new presumption applies only to art. 101/102 TFEU and its national equivalents, but not to other provisions of domestic competition law.

In several MS, the relevance of some prior case-law on passing-on may now be questioned. In France, courts had previously indicated that it was up to the claimant to prove the absence or impossibility of passing-on, an approach that has now been reversed by its transposition measure. In Germany, the Federal Court had made the passing-on defence dependent on showing, not only that the overcharge was passed on, but also that the claimant had not incurred a loss of profit due to a reduction in the amount sold. While it will be difficult for the defendant to prove passing-on or absence thereof, depending on whether the claim is by direct or indirect purchasers, this task is facilitated by the granting of rights of access for that purpose (this point has been specifically clarified in some transpositions, such as in Germany). German law may have been too restrictive when it upholds claims 
for loss of profit only to the extent that these losses were caused by the passing-on of the overcharge. Arguably, this leaves out situations which should also be protected by the right to full compensation, such as loss of profit arising, not from the passing-on of the overcharge itself, but from the exclusion of demand from the market, if it is considered that no price increase was actually passed on to the excluded agents.

In the Netherlands, the Supreme Court already began interpreting national law, in this context, in light of the Directive, even before the transposition was in force. Similarly, the Directive's provisions on passing-on had already been discussed in the English Sainsbury's Supermarkets Ltd v Mastercard Inc \& others case. $^{47}$

\section{Collective redress}

To date in the EU, private enforcement aimed at compensating antitrust damages suffered by consumers and SMEs has been virtually non-existent. ${ }^{48}$ The limited number of cases commenced have mostly been dismissed on procedural grounds or abandoned upon realization of the difficulties faced in ensuring effective redress.

Early on in the drafting of the Directive, it was decided that no provision would be included on collective redress (see recital 13). At the time, the omission was hailed as a victory by business lobbyists, but it soon became apparent that harmonization might have been in their best interest, and the absence of a specific Directive provision may prove in the long run to have been the best possible outcome for consumer interests.

This is because the EU legislator has, until recently at least, fallen captive to the school of thought according to which opt-out representative mechanisms reminiscent in any way of the American class-action system must not be allowed, because they will easily lead to abuse. This was reflected in the Commission's 2013 Recommendation, ${ }^{49}$ which suggested an opt-in mechanism (all the while not excluding the possibility of opt-out in exceptional circumstances), even though there is no example, anywhere in the EU, of an opt-in mechanism ever leading to the compensation of a significant number of consumers. ${ }^{50}$ At the same time, the few MS that have adopted opt-out representative mechanisms have incorporated

\footnotetext{
47 [2016] CAT 11.

48 See, in particular, B Rodger (ed) Competition Law: Comparative Private Enforcement and Collective Redress across the EU (Kluwer 2014).

49 Commission Recommendation of June $11^{\text {th }} 2013$ on common principles for injunctive and compensatory collective redress mechanisms in the Member States concerning violations of rights granted under Union Law (Official Journal L201 of July $26^{\text {th }}$ 2013).

50 In France, UFC-Que-Choisir was a follow-on case in the telecommunications sector. The opt-in action initiated by a consumers association was deemed inadmissible on procedural grounds, with courts affirming that the association could not, under French law, solicit consumers to join the action (as described in M loannidou, Consumer involvement in Private EU Competition Law Enforcement, Oxford University Press, 2015, 128). In Spain, the Ausbanc case failed to move past initial procedural hurdles regarding legitimacy (Order of Provincial Court of Madrid (Sect. 28) of September $30^{\text {th }} 2014$, Ausbanc v. Telefónica, ECLI: ES:APM:2013:2461A). In the UK, two actions failed for procedural reasons, and the only successful one (opt-in) led to the compensation of a very small percentage of the universe of injured consumers. See discussion of the later ('replica kit' case) by B Rodger "A licence to Print (Monopoly) Money? Replica Football Kit and Toys and Games, Resale Price Maintenance and the Competition Act 1998" in B Rodger (ed) Landmark Cases in Competition Law: Around the World in Fourteen Stories (Kluwer 2012).
} 
various levels of safeguards against abuse, seeking to make sure their use is not incentivised by financial motivation, particularly on the part of the legal profession. Interestingly, such safeguards are absent and such motivation appears possible in certain opt-in mechanisms (e.g., where they allow for quota litis or success fee arrangements). Indeed, despite the Recommendation, subsequently the trend has been for some MS that until then only had opt-in collective redress procedures to adopt opt-out mechanisms (Belgium and UK), or to expand (current proposal in the Netherlands) or slightly revise (Portugal) existing opt-out mechanisms. Bulgaria, Denmark and Norway also have slightly varying models of opt-out mechanisms. In some MS, such as Greece and Hungary, an opt-out mechanism is available for consumer protection, but it can only be used (absolutely or in practice, in the vast majority of cases) to obtain an initial declaratory judgment as opposed to a direct claim for damages. Consumers are required subsequently to return to court to obtain their compensation, arguably depriving the mechanism of effectiveness.

The academic literature on collective redress seems to unanimously point to the value and utility of collective opt-out mechanisms, but EU legislators in particular remain reluctant to embrace this, even in light of the unmistakable evidence that the opt-in mechanisms do not work, and cannot work. At the very least, it must be recognized that an opt-in mechanism is incapable of overcoming rational apathy for claims limited to very small amounts (where the opportunity-cost of obtaining information and taking the steps necessary to join the action exceeds the potential benefit).

Nonetheless, allowing opt-out representative actions is not a panacea. As the low usage and lack of success of existing opt-out mechanisms has shown, there are many other details which will determine the success or failure of any representative mechanism, even an opt-out one. The detail of the mechanism created is certainly capable of limiting the effectiveness of the right to collective redress. Economic viability (reduction of financial risk and possibility of recouping costs in case of victory) is a particularly important concern. But the legal culture and attitude of judges towards collective redress may also be significant. In brief, it is arguable, based on the evidence of litigation practice to date, for example, in the UK, that private enforcement has been, and promises to remain for some time, almost entirely reserved for the protection of companies with deep pockets. Collective redress mechanisms appear to be working (e.g., in the trucks cartel), and promise to compensate SMEs, but only in follow-on actions and where (not so) small claims can be bundled together with very large claims. It is perhaps ironic that the European Commission repeatedly stresses an increase in the welfare of consumers as its ultimate goal, but none of its decisions has ever led to compensation of damages to end consumers, and the Damages Directive proposed by the Commission failed to address this issue entirely.

\section{Concluding Remarks}

This article has analysed the implementation of the EU Antitrust Damages Directive in the different legal systems of a selected number of key MS and assessed its potential impact on private enforcement of competition law through damages actions. The Antitrust Damages Directive is often overly focused on public enforcement concerns, and suffers from considerable shortcomings, allowing for a great level of heterogenous application of articles 101/102 TFEU in the MS. For many years to come, courts will be faced with succession of laws issues, where the temporal rules vary depending on the legal system. Even under the new regime, a 
wide range of differing solutions across the MS will inevitably be put to the test before the CJEU, which will have to ensure respect for the principle of effectiveness and the uniform application of EU Competition Law and it will be in a position to determine the new regime's success or failure. One of the issues that will need to be clarified concerns attribution of liability within corporate structures for private enforcement purposes.

Even before it has been applied, it is clear that there is scope for improvement. A particularly striking gap is the absence of concern for consumer protection, made even worse by the unexplained omission of this Directive from the long list of EU legislation subject to the new Commission proposal on representative actions for consumer redress ${ }^{51}$. Nonetheless, there are positive signs in that there is evidence of a considerable number of private damages claims across the national courts of the EU - especially follow-on cartel cases (for instance following the trucks cartel Decision ${ }^{52}$ ) - which may lead to successful damages actions, and enhanced awareness of the potential for this type of remedy.

Furthermore, the new regime has introduced special rules for antitrust damages actions which derogate a great number of general principles and rules of the domestic legal orders of several MS. It is possible that the existence of these special rules in the legal orders of the MS, relating to access to evidence, to timebarring, etc, which were introduced because they were deemed necessary to ensure the effectiveness of the rights being protected, will, in the long run, lead to a broader debate about the justification of the more restrictive general regimes in a number of MS.

\footnotetext{
51 Proposal for a Directive of the European Parliament and of the Council on representative actions for the protection of the collective interests of consumers, and repealing Directive 2009/22/EC, April $11^{\text {th }} 2018, \operatorname{COM}(2018) 184$ final.

52 Decisions of the European Commission of July $19^{\text {th }} 2016$ and September $27^{\text {th }} 2017$ (AT.39824 Trucks).
} 